\title{
Research Notes
}

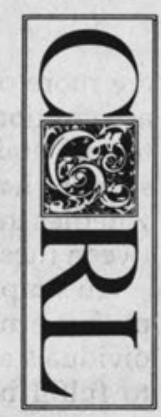

\section{Learning Styles of Academic Librarians}

\author{
Jin M. Choi
}

Characteristics of learning styles of 140 academic librarians in public and technical services were examined based on Kolb's Learning Style Inventory. The most common learning styles among academic librarians were found to be the assimilator (38.6 percent) followed by the converger (27.1 percent), indicating librarians' strengths in abstract conceptualization. Contrary to folklore in the field, the learning styles of technical and public services librarians show no statistically significant differences. In addition, the relationships between learning styles and other variables such as sex, age group, undergraduate major, and length of professional experience are discussed.

As the social and technological environment of libraries changes rapidly, so also has the nature of library services and professional practices changed. Development of new information technologies seems to be the single most important agent of change and to have had profound impact upon library and information professionals. Although we do not have empirical data to assess the impact of such change, nor to predict the future of our profession, what seems evident is that the current situation requires reorganization in libraries and changes in staff and demands new knowledge and skills from professional librarians. Continuing education seems to be the most logical coping mechanism for such change.

Unfortunately, in attempts to manage this change in libraries through professional development, library administrators seem to operate on rules of thumb rather than on a sold knowledge of the individual needs of the professionals. For example, it is frequently mentioned in the literature that the application of technology - such as integrated library automation-will alter the traditional division between technical and public services. ${ }^{1-3}$ At the same time, it is asserted that "individual librarians are not as interchangeable within libraries as most administrators would like to assume. ${ }^{\prime 4}$ In addition, there has been a long-standing belief about the dichotomy between technical and public services-the "'backroom/ frontroom library mentality. ${ }^{15}$ Many assume that librarians in technical services are "different" from those in public services in that those in technical services tend to be more analytical and oriented toward things while those in public services

Jin M. Choi is Assistant Professor at the College of Library and Information Services, University of Maryland, College Park, Maryland 20742. This research was made possible by a Faculty/Librarian Cooperative Research Grant funded by the Council on Library Resources. The author thanks Nancy Washington, Assistant Director of Library Processing Center, University of South Carolina, who coauthored a report ('Learning Styles of Academic Librarians and Implications for Professional Developments"'), and Shika Mathur for her research assistance. 
are more oriented toward people. These assumptions, however, have never been tested, and library administrators do not seem to have adequate knowledge about whether there are any real differences between these two.types of librarians.

We simply do not know how to accomplish the most effective match between individuals and work assignments in order to fulfill both individual and organizational needs. Nor do we know how to provide avenues of career development that promote utilization of human resources in the most effective way within the profession. Perhaps it is time for us to take a close look at individual differences in learning styles or cognitive styles to determine if such knowledge could provide meaningful insights or valid guidance for the effective match between individuals and work assignments, as well as for career development within the profession.

A literature survey of the last twenty years demonstrates that research interest in cognitive and learning styles in the field of library and information science has increased gradually. Research interest in this area has been drawn from two perspectives: One group of researchers, for example, Tefko Saracevic and Paul Kantor, ${ }^{6}$ Christin Borgman, ${ }^{7}$ Trudi Bellardo, ${ }^{8}$ H. Elkerton and R.C. Williges, ${ }^{9}$ S. Sitton and G. Chmelir, ${ }^{10}$ and N. N. Woelfl, ${ }^{11}$ investigated cognitive styles or learning styles as a way to understand individual differences in performance in using computers. The other group of researchers, for example, B. L. Stein and others, ${ }^{12}$ Stein and H. L. Totten, ${ }^{13}$ S. J. McIntire and C. L. McIntire, ${ }^{14}$ D. H. Jonassen and G. G. Hodges, ${ }^{15}$ Kerry Johnson and Marilyn White, ${ }^{16}$ and Jana Varlejs, ${ }^{17}$ examined cognitive styles or learning styles of students enrolled in library and information science programs concerning career counseling. However, knowledge about the learning styles of practicing professional librarians still seems to be inadequate.

In this context, the purposes of this study are (1) to identify the predominant learning style of academic librarians working in public and technical services; (2) to determine if the learning styles of academic librarians working in public ser- vices and those in technical service are significantly different; and (3) to assess the relationships between learning styles and other variables, such as sex, age group, undergraduate major, and length of professional experience.

\section{THEORETICAL FRAMEWORK: KOLB'S EXPERIENTIAL LEARNING THEORY}

The theoretical framework of this study is based on David Kolb's experiential learning theory ${ }^{18-20}$ and his Learning Style Inventory. ${ }^{21,22}$ Kolb's model conceptualizes the learning process as a four-stage cycle and identifies four different learning styles. Kolb's learning cycle includes concrete experience $(\mathrm{CE})$, reflective observation (RO), abstract conceptualization (AC), and active experimentation (AE), which suggests that one learns from concrete experience, then concrete experience forms the basis for observation and reflection, which in turn leads to formation of abstract concepts and generalizations. This formation of concepts and generalizations then guides the choice of new experiences. Kolb, however, recognized two dialectic dimensions of the learning process: the concrete/abstract (AC-CE) and the active/reflective (AE-RO) dimensions. According to Kolb, in the process of learning, we tend to resolve this dialectic tension by accentuating one ability over the other. Thus, learning styles represent an individual's learning preference between these two dimensions. As a result, there are four learning styles (or learning style quadrants). They are the converger, the diverger, the assimilator, and the accommodator, as shown in figure 1.

To be specific, the converger tends to prefer abstract and active learning modes. $\mathrm{Kolb}$ found that convergers tend to have strengths in the practical application of ideas and they tend to be unemotional, preferring to deal with things rather than people. This learning style is typical of individuals with engineering and physical science backgrounds. Divergers are the opposite of convergers in that they tend to prefer reflective and concrete learning modes and they tend to be emotional and interested in people. This style is charac- 


\section{CONCRETE EXPERIENCE}

ACCOMMODATOR
Getting things done
Risk taking
Leadership
Careers in Organizations
Managers
Managers/Accountants
Careers in Business
Marketing-Salesperson
Government-Politician

ACTIVE EXPERIMENTATION

\section{CONVERGER}

Problem solving Defining problems Deductive reasoning

Careers as Specialists

Economics

Careers in Technology

Medicine

Computer Science

Physical Science

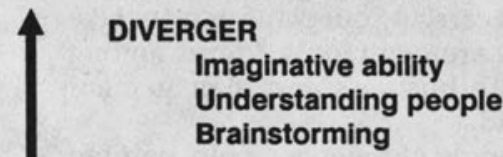

\section{Careers in Arts}

Literature, Artists

Careers in Service Organizations

Social Work

Psychology

\section{ASSIMILATOR}

\section{Planning}

Defining problems

Developing theories

Information Careers

Education-Teacher/Librarian Sociology

Careers in Science

Mathematics

Physical Science

Biology

Researcher

\section{ABSTRACT CONCEPTUALIZATION}

FIGURE 1

Four Learning Style Quadrants

teristic of people with humanities and liberal arts backgrounds. Assimilators prefer abstract and reflective learning modes, and they are less interested in people and are less concerned with the practical use of theories. Kolb found that individuals with science careers or information careers, such as teacher, librarian, minister, or college professor, tend to have the assimilative learning style. Accommodators are 
the opposite of assimilators in that their strengths lie in concrete experience and active experimentation. Accommodators are good at carrying out plans, tend to take risks, and are commonly found among people with business and management background. $^{23}$

Interestingly, however, Kolb pointed out that learning styles are adaptive. They can be modified and accentuated in a way to match individual characteristics and environmental demands. Kolb further stated that such matches come about in two ways: either environments tend to engender changes in individual characteristics to fit them, or individuals tend to select themselves into environments that are consistent with their personal characteristics. Based on this conceptual framework, Kolb devised an instrument called the Learning Style Inventory to map one's learning style into the learning style quadrants (i.e., converger, diverger, etc.). Basically, Kolb's study led him to generalize that individuals who are in a similar career tend to have a similar learning style and that deviation from the career path takes place if there is a mismatch between individual characteristics and career environment. One of the underlying implications of Kolb's theory is that one can identify the predominant learning style of a group of people in a certain field and use this information as a basis to guide career choice, career development, and instructional design.

\section{METHODOLOGY}

The Learning Style Inventory 1985 (LSI) and a supplementary questionnaire were used to obtain data on learning styles and other individual attributes. Survey instruments were distributed to 200 librarians working in technical service and public service (100 for each group) of twenty member-libraries of the Association of Research Libraries. A total of 148 (74 percent) of those surveyed returned the materials.

The LSI generates six scores: four basic scores and two combination scores. The four basic scores are the sum of ranking scores (between one and four) for each of the four categories, that is, concrete experience $(\mathrm{CE})$, reflective observation (RO), abstract conceptualization (AC), and active experimentation (AE). Two combination scores reflect one's preference on the two dialectic dimensions and are obtained by AC-CE and AE-RO. Learning style quadrants were determined by plotting the two combination scores on the learning style grid.

Data on demographic variables such as sex, age, undergraduate major, and length of professional experience were obtained by the supplementary questionnaire.

\section{RESULTS \\ Profile of Respondents}

Of 148 respondents, 8 returned either incomplete or unusable LSIs and were subsequently eliminated. Of 140 accepted returns, 73 ( 52 percent) were from technical services and 67 (48 percent) were from public services (table 1). All in all, the major characteristics of the respondents were as expected (table 2): they were female, between thirty and fifty years of age, had a varying range of professional experiences, and had majored in the humanities.

\section{Predominant Learning Style among Academic Librarians}

The most common learning style among the academic librarians surveyed was found to be the assimilator (38.6 percent), followed by the converger ( 27.1 percent), the diverger (19.3 percent), and the accommodator (15 percent). As stated, assimilators tend to prefer reflective and abstract modes of learning and convergers prefer active and abstract modes of learning. Thus, one can safely state that a ma-

TABLE 1

SURVEY RESPONSE

\begin{tabular}{lccc}
\hline \hline & Number Distributed & Number Returned & Number Completed \\
\hline Technical services & $100(50 \%)$ & $73(51 \%)$ & $73(52 \%)$ \\
Public services & $100(50 \%)$ & $75(49 \%)$ & $67(48 \%)$ \\
Total & $200(100 \%)$ & $148(100 \%)$ & $140(100 \%)$ \\
\hline
\end{tabular}


TABLE 2

\section{PROFILE OF RESPONDENTS}

\begin{tabular}{lrr}
\hline \hline & Number & Percent \\
\hline Sex & 48 & 34.3 \\
Male & 42 & 65.7 \\
Female & 92 & \\
Age group & 13 & 9.3 \\
$<$ 30 & 54 & 38.6 \\
$30-40$ & 54 & 38.6 \\
$40-50$ & 19 & 13.6 \\
$>50$ & 40 & 28.6 \\
Length of experience & 25 & 17.9 \\
1-5 yr & 32 & 22.9 \\
$5-10$ yr & 43 & 30.7 \\
10-15 yr & \\
>15 yr & 101 & 72.1 \\
Undergraduate major & 31 & 22.1 \\
Humanities & 7 & 5.0 \\
Social science & \\
Science & \\
\hline
\end{tabular}

jority of academic librarians tend to prefer or have strength in abstract conceptualization. Kolb described assimilators as individuals who are "best at understanding a wide range of information and putting it into concise, logical form, and they are less focused on people and more interested in abstract ideas and concepts." 24

Given the nature of the profession, it is not surprising that academic librarians tend to have assimilative and convergent learning styles. The fact that the assimilative learning style is the most common among academic librarians is consistent with Kolb's finding. What is interesting and contrasts with Kolb's generalization (i.e., the undergraduate major is one of the most influential factors determining one's learning style and individuals with a humanities and liberal arts background tend to have a divergent learning style) is that the majority (72.1 percent) of the respondents had a humanities or liberal arts background; yet their learning styles do not seem to conform to the expected norm (i.e., divergent learning style). Instead, they showed strong preference toward convergent or assimilative learning styles. It is difficult to speculate on the reasons for such discrepancy based on the given data. However, if indeed Kolb's generalization is valid, one could speculate that among the respondents, one of two things might have happened: either the individual left the field of their undergraduate major and chose librarianship among alternatives since it is consistent with their learning style, or the nature of the profession, once they entered it, tended to stress abstract conceptualization (which is the common denominator of assimilators and convergers). Thus, the individual learning styles were modified toward a match with the learning ability emphasized by the profession. Yet, it is only a speculation and requires further investigation. What is evident is that academic librarians seem to prefer or have strengths in abstract conceptualization.

\section{Difference among Learning Styles of Academic Librarians in Technical Services and Public Services}

In contrast to widely held beliefs in the field, public services librarians and technical services librarians showed no statistically significant difference in their learning style distributions. These two groups seem to be quite homogeneous and showed a great deal of similarity in their learning style distributions. As shown in tables 3 and 4 , both the chi-square test on the distribution of learning style quadrants and the one-way ANOVA test on the mean LSI scores by specialties yielded no statistically significant difference between the groups. It is rather puzzling in that $\mathrm{Kolb}^{25}$ and others ${ }^{26-27}$ found that learning styles do differ among the specialty groups within the field as, for instance, in medical science or business. Again, what accounts for this inconsistency is not clear. However, two explanations are possible: one is that academic librarians are indeed a homogenous group; the other is that Kolb's LSI might not be sensitive enough to detect the differences between subgroups, although it is able to differentiate groups that are profoundly different, as also indicated by Roger Wunderlich and Craig Gjerde. ${ }^{28}$

If Kolb's theory holds true, then the accommodators in this survey would be the most likely group to find conflicts between their choice of career and their learning styles, and an ideal solution would be to guide their career development more toward administration or managerial assignments. However, the question is open and requires more in-depth study. 
TABLE 3

COMPARISON OF LEARNING STYLE QUADRANTS BY SPECIALTIES

\begin{tabular}{|c|c|c|c|c|}
\hline & \multicolumn{4}{|c|}{$\begin{array}{l}\text { Learning Styles } \\
\end{array}$} \\
\hline & Diverger & Accommodator & Assimilator & Converge \\
\hline Technical services & & & & \\
\hline Frequency & 11 & 11 & & 21 \\
\hline Percent & 7.9 & 7.9 & 21.4 & 15 \\
\hline Public services & & & & \\
\hline Frequency & 16 & 10 & 24 & 17 \\
\hline Percent & 11.4 & 7.1 & 17.1 & 12.1 \\
\hline Total & & & & \\
\hline Frequency & 27 & 21 & 54 & 38 \\
\hline Percent & 19.3 & 15.0 & 38.6 & 27.1 \\
\hline
\end{tabular}

Chi-square $=7.815$ (critical); degrees of freedom $=3 ; p=0.05$.

Chi-square $=1.807$ (observed)

TABLE 4

COMPARISON OF MEAN LSI SCORES BY SPECIALTIES

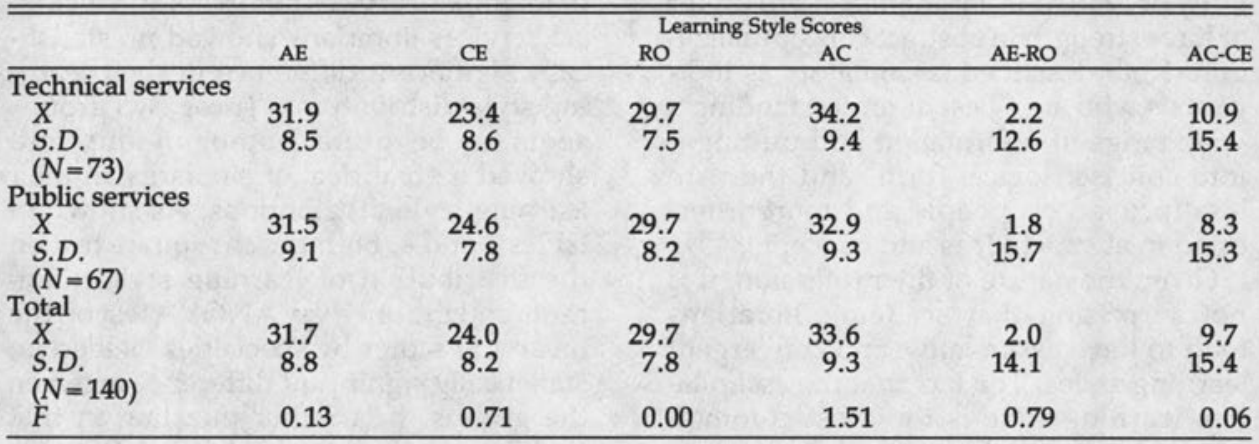

$N=$ sample size; $X=$ Mean; $S . D .=$ standard deviation.

$F=3.841$; degrees of freedom $=1,137 ; p=0.05$.

What is clear is that academic librarians in technical and public services are similar in terms of the distribution of their learning styles-a finding that contradicts the popular perception of the dichotomy between the groups. Thus, one might safely assume that individuals could probably work well in either speciality, provided that appropriate knowledge, skills, and attitude are acquired and updated.

\section{Relationships among Learning Styles and Other Variables}

As shown in table 5, chi-square tests of learning styles by sex, age group, length of experience, and undergraduate major were performed. Although Kolb found that learning styles differ by sex, age group, and undergraduate major, no sta- tistically significant differences were found between the learning styles by gender, age group, length of experience, or undergraduate major. ${ }^{29-30}$ The data hint, however, that more female respondents (25 percent) tend to have a more divergent learning style than do male respondents (8.3 percent). The data also indicate that as the length of experience increases, the convergent learning style tends to strengthen while the divergent learning style tends to weaken. Again, it might be that the nature of the profession shapes one's learning style more toward abstract conceptualization and less toward concrete experience. In other words, the profession seems to demand strengths in abstract conceptualization, so an individual librarian's learning style is modified in 
TABLE 5

COMPARISON OF LEARNING STYLE QUADRANTS BY SEX, AGE GROUP, LENGTH OF EXPERIENCE, AND UNDERGRADUATE MAJORS

\begin{tabular}{|c|c|c|c|c|c|}
\hline & & & & & \\
\hline & $N$ & Diverger & Accommodator & Assimilator & Converger \\
\hline Sex & & & & & \\
\hline Male & 48 & $4(8.3 \%)$ & $9(18.8 \%)$ & $23(47.9 \%)$ & 12 (25\%) \\
\hline $\begin{array}{l}\text { Female } \\
\text { Chi-square }\end{array}$ & $\begin{array}{r}92 \\
=7.005 ; p\end{array}$ & $\begin{aligned} & 23(25 \%) \\
= & 0.072 ; 3 \text { d.f. }\end{aligned}$ & $12(13 \%)$ & $31(33.7 \%)$ & $26(28.3 \%)$ \\
\hline Age group & & & & & \\
\hline$<30$ & 13 & 3 (23.1\%) & $2(15.4 \%)$ & 5 (38.5\%) & $3(23.1 \%)$ \\
\hline $30-40$ & 54 & $9(16.7 \%)$ & $7(13 \%)$ & $21(38.9 \%)$ & $17(31.5 \%)$ \\
\hline $40-50$ & 54 & $14(25.9 \%)$ & $8(14.8 \%)$ & $19(35.2 \%)$ & $13(24.1 \%)$ \\
\hline$>50$ & 19 & $1(5.3 \%)$ & $4(21.1 \%)$ & $9(47.4 \%)$ & $5(26.3 \%)$ \\
\hline Chi-square & $=5.266 ; p$ & $=0.811 ; 9$ d.f. & & & \\
\hline Length of exper & rience & & & & \\
\hline $1-5 \mathrm{yr}$ & 40 & $11(27.5 \%)$ & $6(15 \%)$ & 15 (37.5\%) & $8(20 \%)$ \\
\hline $5-10 \mathrm{yr}$ & 25 & $4(16 \%)$ & $3(12 \%)$ & $10(40 \%)$ & $8(32 \%)$ \\
\hline $10-50 \mathrm{yr}$ & 32 & $6(18.8 \%)$ & $3(9.4 \%)$ & $14(43.8 \%)$ & $9(28.1 \%)$ \\
\hline$>15 \mathrm{yr}$ & 43 & 6 (13.4\%) & 9 (20.9\%) & $15(34.9 \%)$ & $13(30.2 \%)$ \\
\hline Chi-square & $=5.542 ; p$ & $0.785 ; 9$ d.f. & & & \\
\hline Undergraduate & major & & & & \\
\hline Humanities & 101 & $18(17.8 \%)$ & $18(17.8 \%)$ & $37(36.6 \%)$ & $28(27.7 \%)$ \\
\hline Social science & 31 & $8(25.8 \%)$ & $2(6.5 \%)$ & $11(35.5 \%)$ & $10(32.3 \%)$ \\
\hline Science & 7 & $1(14.3 \%)$ & $1(14.3 \%)$ & 5 (71.43\%) & $0(0.0 \%)$ \\
\hline Chi-square & $=8873 . n$ & $=0449.9 \mathrm{df}$ & & & \\
\hline
\end{tabular}

Chi square $=7.815$ (critical); degrees of freedom $=3 ; p<.05$.

Chi square $=16.919$ (critical); degrees of freedom $=9 ; p<.05$.

TABLE 6

COMPARISON OF MEAN LSI SCORES BY SEX, AGE GROUP, LENGTH OF EXPERIENCE, AND UNDERGRADUATE MAJORS

\begin{tabular}{|c|c|c|c|c|c|c|c|}
\hline & & & & Learn & le Score & & \\
\hline & $N(\%)$ & $\mathrm{AE}$ & CE & RO & $\mathrm{AC}$ & AE-RO & AC-CE \\
\hline Sex & & & & & & & \\
\hline Male & 48 (34.3) & 30.8 & 24.0 & 28.4 & 36.0 & 2.4 & 12.0 \\
\hline Female & 92 (65.7) & 32.2 & 24.0 & 30.4 & 32.4 & 1.8 & 8.4 \\
\hline $\begin{array}{c}F \\
\text { Age group }\end{array}$ & - & 0.6 & 0.0 & 2.2 & $4.2^{*}$ & 0.1 & 1.4 \\
\hline $\begin{array}{l}\text { Age group } \\
<30\end{array}$ & & & & & & & \\
\hline $30-40$ & $54(38.6)$ & $\begin{array}{l}33.7 \\
31.8\end{array}$ & 22.2 & $\begin{array}{r}30.6 \\
28.3\end{array}$ & 32.8 & 3.1 & $\begin{array}{r}10.6 \\
9.0\end{array}$ \\
\hline $40-50$ & $54(38.6)$ & 31.5 & 23.8 & 30.6 & 33.2 & 0.8 & 9.4 \\
\hline$>50$ & $19(13.6)$ & 30.8 & 22.3 & 30.3 & 34.0 & 0.6 & 11.7 \\
\hline$F$ & - & 0.3 & $5.3^{*}$ & 0.9 & 0.2 & 0.3 & 0.2 \\
\hline Length of experi & & & & & & & \\
\hline $1-5 \mathrm{yr}$ & $40(28.6)$ & 31.3 & 26.8 & 29.4 & 31.5 & 1.9 & 4.8 \\
\hline $5-10 \mathrm{yr}$ & $25(17.9)$ & 31.4 & 23.2 & 27.6 & 36.8 & 3.8 & 13.6 \\
\hline $10-15 \mathrm{yr}$ & $32(22.9)$ & 31.8 & 23.0 & 29.6 & 34.4 & 2.1 & 11.4 \\
\hline$>15 \mathrm{yr}$ & $43(30.7)$ & 32.2 & 22.4 & 31.2 & 33.0 & 1.0 & 10.6 \\
\hline$F$ & - & 0.2 & 2.2 & 1.1 & 2.0 & 0.2 & 2.1 \\
\hline Undergraduate & & & & & & & \\
\hline Humanities & $101(42.1)$ & 31.6 & 24.1 & 29.0 & 34.2 & 2.6 & 10.0 \\
\hline Social science & 31 (22.1) & 33.8 & 23.4 & 30.4 & 32.3 & 3.4 & 8.9 \\
\hline Science & $7(5.0)$ & 26.4 & 24.2 & 36.0 & 28.7 & -9.6 & 4.9 \\
\hline$F$ & - & 2.2 & 0.1 & 2.8 & 1.5 & 2.7 & 0.5 \\
\hline
\end{tabular}

$F=3.841$; degrees of freedom $=1,137 ; p<.05$.

"Statistically significant. 
that direction over time. Table 6 is a summary of mean LSI scores by sex, age group, length of experience, and undergraduate major.

When one-way ANOVA tests were performed, the mean score of abstract conceptualization varied significantly by sex and the mean score of concrete experience varied significantly among age groups. No significant difference was found between mean LSI scores and length of experience or undergraduate major.

\section{DISCUSSION}

It is quite common for most professional schools to use some sort of inventory for the purpose of career counseling. And the prerequisite for that is to collect data to identify a predominant cognitive style or learning style that typifies the group of practitioners in a field. This study identified the predominant learning style of academic librarians to be the assimilative learning style, followed by the convergent learning style. The study also showed that academic librarians in public and technical services have similar learning style preferences. However, since several aspects of the study contradict Kolb's generalizations, further in-depth examination of the sensitivity of the LSI is needed. Until then, Kolb's theoretical construct and the LSI seem to have limited practical implication due to their failure to discriminate factors involved in career choice and development and their lack of explanatory power.

\section{REFERENCES}

1. Gregor A. Preston, "How Will Automation Affect Cataloging Staff?" Technical Services Quarterly 1:129-36 (1983).

2. Maurice J. Freedman, "Automation and the Future of Technical Services," Library Journal 109:1197-203 (June 1984).

3. Thomas W. Shaughnessy, "Technology and the Structure of Libraries," Libri 32:149-55 (1982).

4. Susan K. Martin, "The Impact of Technology on Libraries and Librarians: A Literature Review," in The Information Society: Issues and Answers, ed. E. J. Josey (Phoenix, Ariz.: Oryx, 1978), p.116.

5. Patricia G. Schuman, "Library Networks: A Means, Not an End," Library Journal 112:33-37 (Feb. 1987).

6. Tefko Seracevic and Paul Kantor, "A Study of Information Seeking and Retrieving. III. Searchers, Searches and Overlap," Journal of the American Society for Information Science 39:197-216 (1988).

7. Christin L. Borgman, "Individual Differences in the Use of Information Retrieval Systems: A Pilot Study," Proceedings of the 49th Annual Meeting of the American Society for Information Science (Medford, N.J.: Learned Information, 1986), p.20-31.

8. Trudi Bellardo, "An Investigation of Online Searcher Traits and Their Relationship to Search Outcome," Journal of the American Society for Information Science 36:241-50 (1985).

9. J. Elkerton and R. C. Williges, "Evaluation of Expertise in a File Search Environment," Proceedings of the Human Factors Society 27th Annual Meeting, ed. A. T. Pope and L. D. Haugh (Santa Monica, Calif.: Human Factors Society, 1983), p.521-25.

10. S. Sitton and G. Chmelir, "The Intuitive Computer Programmer," Datamation 30:137-41 (1985).

11. N. N. Woelfl, "Individual Differences in Online Search Behavior: The Effect of Learning Styles and Cognitive Abilities on Process and Outcome" (Ph.D. diss., Case Western Univ., Cleveland, Ohio, 1984).

12. B. L. Stein and others, "Understanding Preferred Cognitive Styles-A Tool for Facilitating Better Communication," Journal of Education for Library and Information Science 27:38-43 (1983).

13. B. L. Stein and H. L. Totten, "Cognitive Styles: Similarities among Students," Journal of Education for Librarianship 24:38-49 (1983).

14. S. J. McIntire and C. L. McIntire, "A Career Counseling Model Based on Cognitive Style Assessment," Journal of Education for Librarianship 20:198-210 (1980).

15. D. H. Jonassen and G. G. Hodges, "Student Cognitive Styles: Implications for Library Educators," Journal of Education for Librarianship 22:143-53 (1982).

16. Kerry A. Johnson and Marilyn D. White, "The Field Dependence/Field Independence of Information Professional Students," Library Research 3:355-69 (1981).

17. Jana Varlejs, "Learning Styles of Librarians and Satisfaction with Continuing Education Activi- 
ties: Looking for a Match," in Continuing Education: Issues and Challenges, ed. Esther E. Horne (New York: Saur, 1985), p.131-39.

18. David A. Kolb, Experiential Learning Theory: Experience as the Source of Learning and Development (Englewood Cliffs, N.J.: Prentice-Hall, 1984).

19. David A. Kolb, "Management and the Learning Process," California Management Review 18:21-31 (1976).

20. David A. Kolb and Mark S. Plovnik, "The Experiential Theory of Career Development," in Organizational Careers: Some New Perspectives, ed. John Van Maanen (Chichester: Wiley, 1978), p.65-87.

21. David A. Kolb, The Learning Style Inventory, rev. ed. (Boston: McBer \& Co., 1985).

22. David A. Kolb, Learning Style Inventory: Self-scoring Inventory and Interpretation Booklet (Boston: McBer \& Co., 1985).

23. David A. Kolb, Learning Style Inventory 1985: Technical Specifications (Boston: McBer \& Co., 1985).

24. Kolb, Learning Style Inventory: Self-scoring Inventory and Interpretation Booklet, p.7.

25. Kolb and Plovnik, "The Experiential Theory of Career Development."

26. Georgia R. Sadler and others, "Learning Styles and Teaching Implications," Journal of Medical Education 53:847-49 (1978).

27. Mark Plovnick, "Primary Care Career Choices and Medical Student Learning Styles," Journal of Medical Education 50:849-55 (1975).

28. Roger Wunderlich and Craig L. Gjerde, "Another Look at Learning Style Inventory and Medical Career Choice," Journal of Medical Education 53:45-54 (1978).

29. Kolb, Experiential Learning Theory.

30. Kolb, Learning Style Inventory 1985: Technical Specifications.

\section{Let Wisc-Ware Help Your Students With Biology, or Math, or Physics, or...}

Choose from more than 170 MS DOS-based instructional software programs in the Wisc-Ware catalog. Wisc-Ware enables your campus to locate and distribute software in almost every field of study. Many packages run as Windows applications.

Over 80 major institutions now belong to Wisc-Ware, a primary distributor of the latest research and instructional software available for MS DOS-based microcomputers. Campus, Individual and Class License options exist for your institution. A demonstration center with copies of each product is also available for your library or micro lab.

\section{Call 800-543-3201}

For a FREE Membership Guide

Wisc-Ware

University of Wisconsin-Madison

Bitnet: wiscware@wiscmacc 


\section{We've Put Our Reputation Online!

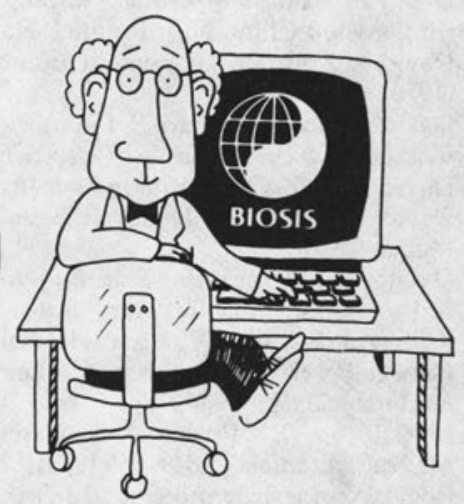

You know us as the producer of Biological Abstracts ${ }^{\star}$. For over 60 years we've been providing coverage of the latest research findings in the life sciences.

We also produce BIOSIS Previews ${ }^{\circledR}$, the online database offering you the largest collection of biological and biomedical references available. This database monitors over 9,000 serial sources from more than 100 countries for news of important life science research findings, noteworthy clinical studies, or discoveries of new organisms. We'll process over 500,000 new items this year. Over 6.5 million citations will be included in the BIOSIS Previews database by the end of 1989 .

Whether you're looking for current life science research findings, or the historical background of a particular topic, BIOSIS Previews can provide you with references to a massive and diverse body of scientific literature. It's the life science research database that will answer your questions.

For more information or to find out how to access BIOSIS Previews, return the coupon below.

Biological Abstracts and BIOSIS Previews are registered trademarks of BIOSIS. BIOSIS is a registered trademark of Biological Abstracts Inc.

\section{Name}

Title

\section{Organization}

\section{Address}

\begin{tabular}{ll}
\hline City & State \\
\hline Postal Code & Country
\end{tabular}

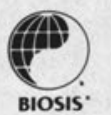

Return to:

BIOSIS Marketing Section, 2100 Arch Street, Philadelphia, PA 19103-1399 USA. Telephone (215) 587-4800 worldwide; toll free 1-800-523-4806 (USA except PA); Telex 831739; Fax (215) 587-2016. 